\title{
EVALUATION OF FIELD GROWN POTATO LINES TRANSGENIC FOR A cry1Ac9 GENE CONFERRING RESISTANCE TO POTATO TUBER MOTH
}

\author{
M.M. DAVIDSON ${ }^{1,2}$, M.F.G. TAKLA ${ }^{1,2}$, J.K. READER ${ }^{1}$, R.C. BUTLER ${ }^{1}$, \\ S.D. WRATTEN ${ }^{2}$ and A.J. CONNER ${ }^{1,2}$ \\ ${ }^{I}$ New Zealand Institute for Crop \& Food Research Limited, Private Bag 4704, \\ Christchurch, New Zealand \\ ${ }^{2}$ Division of Plant, Soil and Ecological Sciences, Lincoln University, P.O. Box 84, \\ Canterbury, New Zealand \\ Corresponding author: davidsonm@crop.cri.nz
}

\begin{abstract}
Phthorimaea operculella (Zeller), potato tuber moth (PTM), is an important pest of potatoes. The larvae of this insect are difficult to control with insecticides because they mine into foliage and tubers. Seven potato cultivars were genetically engineered with a Bacillus thuringiensis cry $1 \mathrm{Ac} 9$ gene to confer resistance to PTM larvae. Fifty-six transgenic lines were established in the field at Lincoln, Canterbury, as small plots of 10 plants along with replicate control plots of the same, but non-transgenic, cultivars. Fortyfour of the transgenic lines were phenotypically normal. Foliage excised from these plants was challenged with PTM larvae in the laboratory. All but one line inhibited larval growth compared to non-transgenic plants $(\mathrm{P}<0.05)$. For transgenic plants the growth indices of larvae fed field-grown foliage were similar to those fed greenhouse-grown foliage. Thirteen of the 43 resistant lines inhibited larval growth by $\geq 40 \%$ and produced tuber yields comparable to the non-transgenic plants.

Keywords: potato tuber moth, transgenic potato plants, $\operatorname{cry} 1 \mathrm{Ac} 9$, insect resistance, cry gene.
\end{abstract}

\section{INTRODUCTION}

Potato tuber moth (PTM) (Phthorimaea operculella) is an economically important pest of potato crops in warm temperate regions, such as New Zealand (Foot 1979), and subtropical climates (Raman \& Palacios 1982; Siddig 1988). Larvae of this insect mine both foliage and tubers. Tubers of potato with larval mines are unmarketable. Larval mines also allow pathogens to enter the tubers (Plaisted et al. 1994). The mines afford the larvae a degree of protection from insecticide sprays, and cultural strategies do not always guarantee protection from infestation. While management of this pest could be augmented by the development of resistant cultivars, traditional breeding methods have failed to produce resistant cultivars (Arnone et al. 1998).

Genetic engineering could provide a viable alternative to traditional breeding methods for developing insect resistant potato plants. Cry genes from Bacillus thuringiensis have been the predominant source for developing PTM resistant potatoes, but most of the work has been limited to greenhouse experiments (Jansens et al. 1995; Li et al. 1999). The purpose of this study was to evaluate the phenotypic appearance and yield of potatoes transgenic for a cry $1 \mathrm{Ac} 9$ gene when grown in the field. Field grown foliage of transgenic lines was used in insect bioassays to determine resistance to PTM larvae.

\section{METHODS}

Genetically engineered potato plants were developed using an Agrobacterium mediated transformation method to transfer a cry1Ac9 gene under the transcriptional 
control of the CaMV 35S promoter (Takla et al. 1999; Davidson 2001). The transgenic lines were evaluated in a containment greenhouse to identify phenotypically normal lines and those with resistance to PTM larvae (inhibited larval growth). Tubers harvested from the transgenic lines and their parent cultivars, were planted in a field at Lincoln, Canterbury, on 23 December 1998. The field trial had been approved by the NZ Environmental Risk Management Authority (permit GMF98008). Ten seed tubers of each transgenic and non-transgenic line were planted $0.3 \mathrm{~m}$ apart in rows of small plots. Plots were separated by $1 \mathrm{~m}$ within a row and $0.75 \mathrm{~m}$ between rows. Lines derived from the same cultivar were planted within neighbouring plots. Replicated non-transgenic plots of a given parent cultivar were positioned randomly among the single transgenic plots. One non-transgenic plot was planted for every three to four transgenic lines belonging to that cultivar. A total of 75 plots were planted, of which 56 were transgenic lines and 19 were non-transgenic lines (Table 1). The foliage and growth of transgenic plants were evaluated 8 to 12 weeks after planting using the categories: phenotypically normal, marginal leaf curl, leaf wrinkling, reduced vigour, stunted growth, and/or spindly appearance of shoots.

Tubers were harvested 18 weeks after planting, in accordance with the field trial approval conditions. Vandalism to the trial on 11 March 1999 prevented tubers from each plant within a plot being harvested separately; instead tubers from all the plants within a plot were harvested together. The number of plants remaining per plot was determined and used to calculate the mean number of tubers per plant, mean weight of tubers per plant and mean weight per tuber.

\section{Insect bioassays using field-grown foliage}

Natural infestation levels of PTM were too low to assess the resistance of transgenic lines in the field. Therefore, foliage excised from phenotypically normal transgenic lines and non-transgenic plants in the field was challenged with PTM larvae in a laboratory using the method described in Davidson et al. (in press). Briefly, this involved weighing 10 neonate larvae together, then placing them on four terminal leaflets excised from plants in the field trial inside a $350 \mathrm{ml}$ plastic container, the bottom of which was lined with dry filter paper (Whatman ${ }^{\circledast}$ No. 1, $75 \mathrm{~mm}$ diameter). Three containers were used for each small plot. Lids were placed on the labelled containers, which were kept in a controlled temperature room at $22^{\circ} \mathrm{C}\left( \pm 3^{\circ} \mathrm{C}\right)$ with a $16: 8 \mathrm{~h}$ light:dark cycle. Larvae were transferred to fresh leaflets of the same transgenic or non-transgenic line after 4 days, and after 10 days recovered larvae were weighed individually. A growth index (GI) was calculated as $\log _{\mathrm{e}}$ (final weight / mean initial weight). Bioassays were conducted over a period of one month.

Statistical analysis

Data from the field trial were initially examined with residual maximum likelihood (REML) methods (Gilmour et al. 1995) to assess whether there were any statistically significant contributions to the variability in the data (variance components) between plots from the same line (larval GI and yield data) or containers from the same plot (larval GI data). REML was used because the unequal numbers of plots, plants and surviving larvae for each line made the data unbalanced. However, the variance components for the plots were not statistically significant $(\mathrm{P}>0.05)$, so could be ignored. This resulted in balanced data sets, allowing ANOVA to be used for the final analyses. Yield data were transformed with logarithms before analysis. The growth indices and yield data of transgenic lines analysed here were part of a larger field trial that included additional transgenic lines not relevant to this study. All statistical analyses were carried out in Genstat 5 release 4.1.

\section{RESULTS AND DISCUSSION}

The 56 phenotypically normal cry1 Ac9-transgenic potato lines that had inhibited larval growth when grown in the greenhouse (Takla et al. 1999; Davidson 2001) were established in the field. The foliage and growth of $79 \%$ of these lines were phenotypically normal in the field (Table 1). The plants considered abnormal (off-types) exhibited stunted growth, 
reduced plant vigour, and/or leaf wrinkling. Off-types are typical of plants regenerated from cell cultures and are often observed among transgenic plant lines (Conner \& Christey 1994). Off-types have often been attributed to somaclonal variation, which involves epigenetic or genetic changes. These changes become more evident under the fluctuating environmental conditions that occur during field trials (Conner et al. 1994).

TABLE 1: Numbers of transgenic potato lines and non-transgenic (control) plots planted for each cultivar in a field trial assessing plant growth and inhibition of potato tuber moth larval growth.

\begin{tabular}{lcccc}
\hline Parent cultivar & $\begin{array}{c}\text { Total no. of } \\
\text { transgenic } \\
\text { lines planted }\end{array}$ & $\begin{array}{c}\text { No. of } \\
\text { control plots } \\
\text { planted }\end{array}$ & $\begin{array}{c}\text { No. of } \\
\text { phenotypically } \\
\text { normal lines }\end{array}$ & $\begin{array}{c}\text { No. of lines to } \\
\text { inhibit PTM larval } \\
\text { growth (P<0.05) }\end{array}$ \\
\hline Iwa & 13 & 4 & 11 & 11 \\
Ilam Hardy & 10 & 3 & 4 & 4 \\
Red Rascal & 14 & 4 & 11 & 10 \\
Russet Burbank & 8 & 3 & 8 & 8 \\
Karaka & 7 & 3 & 6 & 6 \\
Pacific & 3 & 1 & 3 & 3 \\
White Delight & 1 & 1 & 1 & 1 \\
TOTAL & 56 & 19 & 44 & 43 \\
\hline
\end{tabular}

The growth indices of larvae fed field-grown foliage were similar to those fed greenhouse-grown foliage (Takla et al. 1999; Davidson 2001). Foliage from all of the phenotypically normal lines grown in the field reduced larval growth (Fig. 1). For all but one line (D20, derived from Red Rascal) this reduction was statistically significant

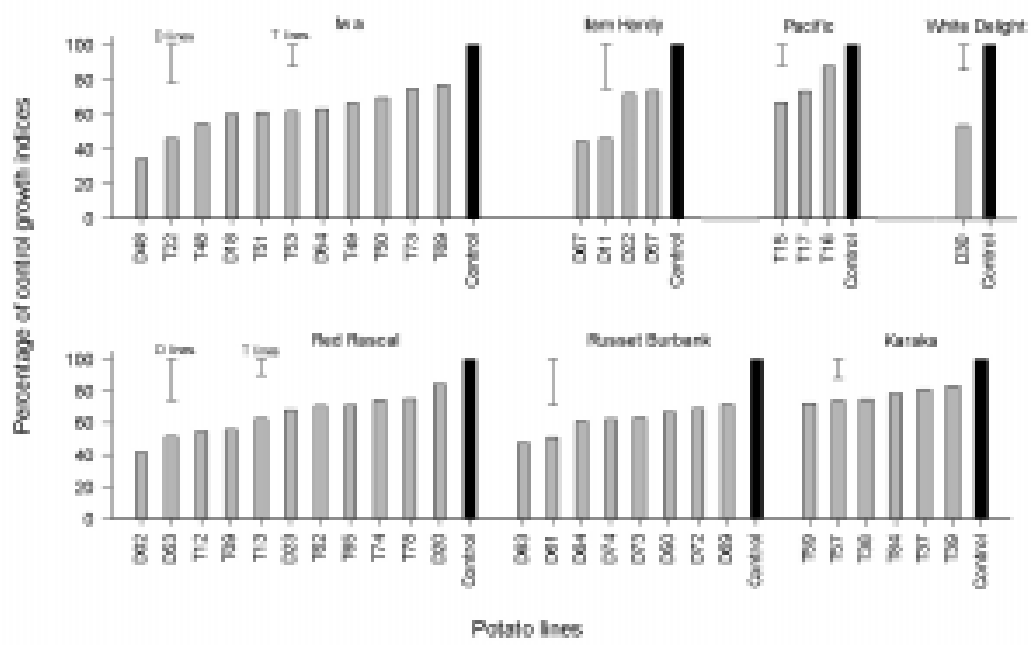

FIGURE 1: Growth indices of PTM larvae fed transgenic foliage as a percentage of larval growth on control (non-transgenic) foliage. Foliage from all transgenic lines inhibited larval growth when compared to their corresponding controls (LSD, $\mathbf{P}<0.05$ ) except D20 (derived from Red Rascal). 
$(\mathrm{P}<0.05)$. The level of larval growth inhibition varied between the transgenic lines (Fig. 1). Such variation is common in independently derived plants transformed with the same transgene (e.g. Jansens et al. 1995; Beuning et al. 2001). It has often been ascribed to "position effects" that result from the random integration of transgenes into different sites of the plant genome (Conner \& Christey 1994).

In a previous study cry1Ac9-transgenic potato lines that inhibited PTM larval growth by $35 \%$, resulted in $83-97 \%$ mortality of PTM when the insects were allowed to develop through to adults (Davidson et al. in press). In this study, 13 of the resistant lines inhibited larval growth by $\geq 40 \%$ and were, therefore, considered to have a high level of resistance to PTM larvae. The highly resistant lines also produced yields that were similar $(\mathrm{P}>0.05)$ to their corresponding parental control yields, for all three parameters measured (Table 2).

TABLE 2: The transgenic lines that produced yields similar $(\mathbf{P}>\mathbf{0 . 0 5})$ to their corresponding parental cultivar (control) for all three yield parameters and inhibited PTM larval growth by $\geq 40 \%$.

\begin{tabular}{|c|c|c|c|c|}
\hline Cultivar and line & $\begin{array}{l}\text { Mean no. of } \\
\text { tubers per plant }\end{array}$ & $\begin{array}{l}\text { Mean wt of } \\
\text { tubers per plant }(\mathrm{g})\end{array}$ & $\begin{array}{l}\text { Mean wt per } \\
\text { tuber }(\mathrm{g})\end{array}$ & $\begin{array}{l}\text { Mean larval } \\
\text { growth index }\end{array}$ \\
\hline \multicolumn{5}{|l|}{ Iwa } \\
\hline Control & 7.2 & 1058 & 160 & 5.5 \\
\hline D18 & 9.6 & 816 & 85 & 3.1 \\
\hline D48 & 8.6 & 667 & 78 & 1.8 \\
\hline LSD $(\mathrm{P}<0.05)^{1}$ & - & - & - & 1.2 \\
\hline $\mathrm{T} 22$ & 11.0 & 838 & 76 & 2.7 \\
\hline $\mathrm{T} 48$ & 8.0 & 873 & 109 & 3.2 \\
\hline LSD $(\mathrm{P}<0.05)$ & 6.1 & 705 & 129 & 0.7 \\
\hline \multicolumn{5}{|l|}{ Ilam Hardy } \\
\hline Control & 6.3 & 684 & 123 & 5.5 \\
\hline D67 & 7.0 & 601 & 86 & 2.4 \\
\hline LSD $(\mathrm{P}<0.05)$ & 6.4 & 737 & 135 & 1.4 \\
\hline \multicolumn{5}{|l|}{ Red Rascal } \\
\hline Control & 11.7 & 896 & 78 & 5.5 \\
\hline D02 & 6.0 & 601 & 100 & 2.1 \\
\hline D53 & 7.7 & 649 & 85 & 2.6 \\
\hline LSD $(\mathrm{P}<0.05)$ & - & - & - & 1.4 \\
\hline T09 & 6.7 & 608 & 91 & 3.3 \\
\hline $\mathrm{T} 12$ & 8.5 & 666 & 78 & 3.2 \\
\hline LSD $(\mathrm{P}<0.05)$ & 6.4 & 737 & 135 & 0.6 \\
\hline \multicolumn{5}{|l|}{ Russet Burbank } \\
\hline Control & 7.2 & 976 & 141 & 5.6 \\
\hline D61 & 8.8 & 643 & 73 & 2.9 \\
\hline D63 & 6.1 & 756 & 123 & 2.7 \\
\hline D64 & 9.5 & 875 & 92 & 3.4 \\
\hline LSD $(\mathrm{P}<0.05)$ & 6.6 & 761 & 140 & 1.6 \\
\hline \multicolumn{5}{|l|}{ White Delight } \\
\hline Control & 2.6 & 148 & 57 & 5.4 \\
\hline D30 & 3.7 & 205 & 56 & 2.9 \\
\hline LSD $(\mathrm{P}<0.05)$ & 8.1 & 932 & 171 & 0.8 \\
\hline
\end{tabular}

${ }^{1}$ The growth indices for the $\mathrm{D}$ and $\mathrm{T}$ lines were analysed separately, resulting in different LSDs for each group, within the cultivars. The yield data for both D and T lines was analysed together resulting in a single LSD for each cultivar. 
Screening a relatively large number of new transgenic lines for the first time in the field is an effective way of eliminating off-types. The visual classification of foliage appearance gave a strong indication of potential yield. Severe off-types often produced extremely small $(<10 \mathrm{~g} /$ tuber $)$ and/or knobbly tubers. All of the transgenic lines listed in Table 2 produced phenotypically normal tubers. The large LSDs calculated for the yield analysis is a reflection of the inherently high variability typically found between and within potato plants. However, this variability was further exacerbated by having to determine the number of plants remaining after the vandalism and having to combine the tubers of all the plants left in a plot at harvest. Despite this, we were able to identify elite transgenic lines worthy of further testing in larger-scale field trials.

\section{ACKNOWLEDGEMENTS}

Dr Dharshini Ganeshan assisted with the bioassays, and Crop \& Food Research personnel assisted with planting and harvesting field trials. A Technology for Industry Fellowship from the Foundation for Research Science and Technology with Lincoln University and Alex McDonald (Merchants) Ltd provided financial support for M.M. Davidson. Crop \& Food Research and Alex McDonald (Merchants) Ltd provided financial assistance for M.F.G. Takla.

\section{REFERENCES}

Arnone, S.; Musmeci, S.; Bacchetta, L.; Cordischi, N.; Pucci, E.; Cristofaro, M.; Sonnino, A. 1998: Research in Solanum spp. of sources of resistance to the potato tuber moth Phthorimaea operculella (Zeller). Potato Res. 41: 39-49

Beuning, L.L.; Mitra, D.S.; Markwick, N.P.; Gleave, A.P. 2001: Minor modifications to the $\operatorname{cry} 1 \mathrm{Ac} 9$ nucleotide sequence are sufficient to generate transgenic plants resistant to Phthorimaea operculella. Ann. Appl. Biol. 138: 281-292.

Conner, A.J.; Christey, M.C. 1994: Plant breeding and seed marketing options for introduction of transgenic insect-resistant crops. Biocontrol Sci. Technol. 4: 463473.

Conner, A.J.; Williams, M.K.; Abernethy, D.J.; Fletcher, P.J.; Genet, R.A. 1994: Field performance of transgenic potatoes. N.Z. J. Crop Hort. Sci. 22: 361-371.

Davidson, M.M. 2001: Management of genetically engineered potatoes resistant to potato tuber moth, Phhorimaea operculella (Lepidoptera: Gelechiidae). $\mathrm{PhD}$ thesis, Lincoln University, Canterbury.

Davidson, M.M.; Jacobs, J.M.E.; Reader, J.K.; Butler, R.C.; Frater, C.M.; Markwick, N.P.; Wratten, S.D.; Conner, A.J. in press: Development and evaluation of potatoes transgenic for a cry $1 \mathrm{Ac} 9$ gene conferring resistance to potato tuber moth. J. Amer. Soc. Hort. Sci. in press.

Foot, M.A. 1979: Bionomics of the potato tuber moth, Phthorimaea operculella (Lepidoptera: Gelechiidae), at Pukekohoe. N.Z. J. Zool. 6: 623-636.

Gilmour, A.R.; Thompson, R.; Cullis, B.R. 1995: Average information REML, an efficient algorithm for variance parameter estimation in linear mixed models. Biometrics 51:1440-1450.

Jansens, S.; Cornelissen, M.; de Clercq, R.; Reynaerts, A.; Peferoen, M. 1995: Phthorimaea operculella (Lepidoptera: Gelechiidae) resistance in potato by expression of the Bacillus thuringiensis CryIA(b) insecticidal crystal protein. $J$. Econ. Entomol. 88: 1469-1476.

Li, W.B.; Zarka, K.A.; Douches, D.S.; Coombs, J.J.; Pett, W.L.; Grafius, E.J. 1999: Coexpression of potato $\mathrm{PVY}^{\circ}$ coat protein and cry5-Bt genes in potato. J. Amer. Soc. Hort. Sci. 124: 218-23

Plaisted, R.L.; Bonierbale, M.W.; Yencho, G.C.; Pineda, O.; Tingey, W.M.; Van den Berg, J.; Ewing, E.E.; Brodie, B.B. 1994: Potato improvement by traditional breeding and opportunities for new technologies. In: Belknap, W.R.; Vayda, M.E.; Park, 
W.D. ed. The Molecular and Cellular Biology of the Potato. CAB International, Wallingford, UK. Pp. 1-20.

Raman, K.V.; Palacios, M. 1982: Screening potato for resistance to potato tuberworm. Entomol. Soc. Amer. 75: 47-49.

Siddig, S.A. 1988: Cultural means of controlling potato tuber moth (Phthorimaea operculella (Zell)) and improvement of potato yield and quality in the Sudan. Acta Hort./Trop. Hort. 218 / XII: 281-288.

Takla, M.F.G; Davidson, M.M.; Reader, J.K; Conner, A.J.; Wratten, S.D. 1999: Transformation of potato cultivars with a cry 1 Ac gene for improved resistance to potato tuber moth. Forestry Research Bulletin 213: 27. 